ARTICLE

\title{
Black carbon footprint of human presence in Antarctica
}

\author{
Raúl R. Cordero (1) 1, Edgardo Sepúlveda1, Sarah Feron ${ }^{1,2}{ }^{\infty}$, Alessandro Damiani $^{3 凶}$, Francisco Fernandoy (D) 4 , \\ Steven Neshyba ${ }^{5}$, Penny M. Rowe ${ }^{6}$, Valentina Asencio ${ }^{7}$, Jorge Carrasco (10 ${ }^{8}$, Juan A. Alfonso ${ }^{9}$, \\ Pedro Llanillo (10 ${ }^{10}$, Paul Wachter (iD ${ }^{11}$, Gunther Seckmeyer ${ }^{12}$, Marina Stepanova ${ }^{1 凶}$, Juan M. Carrera ${ }^{1}$, \\ Jose Jorquera ${ }^{1}$, Chenghao Wang (iD ${ }^{13}$, Avni Malhotra (1) ${ }^{14}$, Jacob Dana ${ }^{15}$, Alia L. Khan ${ }^{15,16}$ \& Gino Casassa ${ }^{8}$
}

Black carbon (BC) from fossil fuel and biomass combustion darkens the snow and makes it melt sooner. The BC footprint of research activities and tourism in Antarctica has likely increased as human presence in the continent has surged in recent decades. Here, we report on measurements of the $\mathrm{BC}$ concentration in snow samples from 28 sites across a transect of about $2,000 \mathrm{~km}$ from the northern tip of Antarctica $\left(62^{\circ} \mathrm{S}\right)$ to the southern Ellsworth Mountains $\left(79^{\circ} \mathrm{S}\right)$. Our surveys show that BC content in snow surrounding research facilities and popular shore tourist-landing sites is considerably above background levels measured elsewhere in the continent. The resulting radiative forcing is accelerating snow melting and shrinking the snowpack on BC-impacted areas on the Antarctic Peninsula and associated archipelagos by up to $23 \mathrm{~mm}$ water equivalent (w.e.) every summer.

\footnotetext{
${ }^{1}$ Universidad de Santiago de Chile. Av. Bernardo O'Higgins, 3363 Santiago, Chile. ${ }^{2}$ University of Groningen, 8911 CE Leeuwarden, The Netherlands. ${ }^{3}$ Center for Environmental Remote Sensing, Chiba University, 1-33 Yayoicho, Inage Ward, Chiba 263-8522, Japan. ${ }^{4}$ Universidad Andrés Bello, Quillota 980, Viña del Mar, Chile. ${ }^{5}$ University of Puget Sound, Department of Chemistry, Tacoma, WA, USA. ${ }^{6}$ NorthWest Research Associates, Redmond, WA, USA. ${ }^{7}$ Select Carbon Pty Ltd, 562 Wellington Street, Perth, WA 6000, Australia. ${ }^{8}$ University of Magallanes, Av. Manuel Bulnes 1855, Punta Arenas, Chile. ${ }^{9}$ Instituto Venezolano de Investigaciones Cientificas (IVIC), Apartado, 20632 Caracas, Venezuela. ${ }^{10}$ Alfred Wegener Institute (AWI), Am Handelshafen 12,27570 Bremerhaven, Germany. ${ }^{11}$ German Aerospace Center (DLR), German Remote Sensing Data Center (DFD), Wessling, Germany. ${ }^{12}$ Leibniz Universität Hannover, Herrenhauser Strasse 2, Hannover, Germany. ${ }^{13}$ Department of Earth System Science, Stanford University, Stanford, CA 94305, USA. ${ }^{14}$ University of Zurich, Winterthurerstrasse 190, 8057 Zürich, Switzerland. ${ }^{15}$ Western Washington University, 516 High St, Bellingham, WA 98225, USA. ${ }^{16}$ National Snow and Ice Data Center, Cooperative Institute for Research in Environmental Sciences, University of Colorado-Boulder, Boulder, CO, USA.

凶email: s.c.feron@rug.nl; damiani@chiba-u.jp; marina.stepanova@usach.cl
} 
$\mathrm{D}$ eposition of light-absorbing impurities (such as crustal dust and soot) onto snow-covered surfaces reduces the albedo, increases the fraction of solar energy absorbed, and accelerates melting ${ }^{1}$. Soot or black carbon (BC) is primarily produced during combustion in diesel engines, coal burning, wildfires, and residential wood burning ${ }^{2}$ and may undergo regional and intercontinental transport during its short atmospheric lifetime. As a result, BC has been found (although at concentrations much lower than in source regions) in snow samples from remote regions in the Arctic ${ }^{3-7}$, North America ${ }^{8,9}$, Northern China ${ }^{10}$, the Tibetan Plateau ${ }^{11}$, the Nepalese Himalayas ${ }^{12}$, and the Andes ${ }^{13,14}$.

The presence of $\mathrm{BC}$ has been also confirmed in Antarctic snow ${ }^{15-18}$ and in Antarctic ice cores ${ }^{19-21}$. These efforts have shown that background levels of $\mathrm{BC}$ in the Antarctic cryosphere, expressed as a concentration in mass per unit mass of meltwater extracted (e.g., $\mathrm{ng} / \mathrm{g}$ ), are consistently below $1 \mathrm{ng} / \mathrm{g}$, at least one order of magnitude lower than in Arctic snow ${ }^{3-7}$.

The remarkably low background concentrations of $\mathrm{BC}$ in Antarctica are compatible with simulations of long-range $\mathrm{BC}$ transport from prominent sources in the Southern Hemisphere ${ }^{22,23}$ and with observations of episodic intercontinental transport of aerosols. Smoke from wildfires in South America ${ }^{24}$ and in Australia ${ }^{25,26}$ has been detected over Antarctica as well as dust originating in Central Australia ${ }^{27}$ and in southern Patagonia ${ }^{28}$. However, back-trajectory analysis suggests that long-range transport plays only a minor role as a source of absorbing aerosols in Antarctica ${ }^{29}$.

As limited meridional airborne transport restricts southward dispersal ${ }^{30}$, local sources appear to dominate deposition of lightabsorbing impurities in Antarctica. Ice-free areas in the northeast Antarctic Peninsula (about $312 \mathrm{~km}^{2}$ ) drive dust deposition into that region ${ }^{31,32}$, while $\mathrm{BC}$ content in snow surrounding research stations, such as Palmer Station ${ }^{16}$, McMurdo Dry Valley Field Stations ${ }^{17}$ and the Amundsen-Scott South Pole Station ${ }^{18}$, has been shown to be considerably above background levels.

The BC footprint of local activities in Antarctica has likely increased as human presence in the continent has surged (Fig. 1). Vessels, airplanes, diesel power plants, generators, helicopters, and trucks are all local $\mathrm{BC}$-rich sources that affect snow several kilometers downwind ${ }^{16,18}$. According to data from the Council of Managers of National Antarctic Programs (COMNAP) ${ }^{33}$ and the Antarctic Treaty Secretariat (ATS) ${ }^{34}, 76$ research stations are actively in use within the Antarctic Treaty area, providing accommodation for ca. 5500 people in summer. Some of these research facilities have developed into logistic hubs. Most stations are on or near the coast, and about half are located on the northern Antarctic Peninsula and associated archipelagos. The vast majority of tourist shore landings also occur in that region ${ }^{35}$. According to the International Association of Antarctica Tour Operators $(\text { IAATO })^{36}, \sim 74,000$ tourists visited Antarctica in the 2019-2020 season, a 32\% increase from the 2018-2019 season, and more than twice the total a decade ago. Of the visitors who travelled with IAATO members to Antarctica, most come by cruise ship but $\sim 1 \%$ travelled by aircraft to destinations in the continental interior, such as Union Glacier Camp ( $79^{\circ} \mathrm{S}$, Ellsworth Mountains).

Here, we report on a large-scale survey of the $\mathrm{BC}$ footprint of local anthropogenic activities (research and tourism) in Antarctica. Although we also sampled at two sites in the interior of the continent, we focused on the Antarctic Peninsula and associated archipelagos that, unlike the rest of the continent, have no large areas left untouched by humans. We measured the BC content in 155 snow samples collected in four consecutive summer seasons (from 2016-2017 to 2019-2020) at a total of 28 sites across a transect of about $2000 \mathrm{~km}$ from the northern tip of Antarctica (King George Island, $62^{\circ} \mathrm{S}$ ) to the southern Ellsworth Mountains (Union Glacier Camp, $79^{\circ} \mathrm{S}$ ); see Table 1 for further details.

\section{Results}

BC concentration. We applied the Meltwater Filtration (MF) Technique $e^{4-10,13,18}$ that required vacuum-filtering the sample meltwater. Filters were analyzed for their content of light-absorbing impurities by spectrophotometry. The spectrally resolved change in light transmission through the filters was then interpreted as an equivalent absorption by a certain mass of light-absorbing material per unit area of the filter. The equivalent absorption allowed us to assess the Ångström exponent of light-absorbing impurities in samples and, by apportioning the absorption to $\mathrm{BC}$ and non-BC components, to estimate the nanograms of $\mathrm{BC}$ per gram of snow (e.g., ng/g).

Since we aimed to assess the influence of light-absorbing impurities on the albedo of representative areas, sampling sites were chosen to be always hundreds of meters (when possible, several kilometers) away from apparent BC sources such as research stations, tourist shore landings, roads, and airfields (Supplementary Fig. 1). On the Antarctic Peninsula, our sampling expeditions roughly mirrored typical touristic routes. Most cruises visit the South Shetland Islands and the Palmer Archipelago also visiting small islands off the Antarctic Peninsula such as Cuverville $\left(64^{\circ} \mathrm{S}\right)$, Petermann $\left(65^{\circ} \mathrm{S}\right)$, and Detaille $\left(67^{\circ} \mathrm{S}\right)$. We also sampled at the northern tip of the Antarctic Peninsula $\left(63^{\circ} \mathrm{S}\right)$; specifically at Hope Bay (the site of the Argentinian Antarctic settlement Esperanza Base) and nearby the Chilean O'Higgins Station (about $30 \mathrm{~km}$ southwest of the northernmost point of the continent). In the Ellsworth Mountains, we sampled at Union Glacier $\left(79^{\circ} \mathrm{S}\right)$, at 2 sites that are about $6 \mathrm{~km}$ East of a blue-ice runway and $1 \mathrm{~km}$ from the designated landing sites for ski-equipped airplanes.

The BC content found in our snow samples was considerably above background levels measured elsewhere in the continent ${ }^{15-21}$. The median of BC concentrations was about $3 \mathrm{ng} / \mathrm{g}$ (Fig. 2), which is close to the median of $\mathrm{BC}$ concentrations in snow samples collected in Greenland ${ }^{5,6}$ but is still well below BC concentrations measured in any other distant region such as the Arctic ${ }^{3-7}$, North America ${ }^{8,9}$, Northern China ${ }^{10}$, the Tibetan Plateau ${ }^{11}$, the Nepalese Himalayas ${ }^{12}$, and the Andes ${ }^{13,14}$. The $\mathrm{BC}$ content of snow in remote regions of the northern hemisphere is on the order of $20 \mathrm{ng} / \mathrm{g}^{37}$.

A latitude dependence of BC concentration is apparent in Fig. 2b. On the northern South Shetland Islands (including King George Island and Greenwich Island) BC concentration generally ranged from 3 to $5 \mathrm{ng} / \mathrm{g}$, while on the southern South Shetland Islands (including Livingston Island) and the northern tip of the Antarctic Peninsula (the Trinity Peninsula) BC concentration generally ranged from 4 to $7 \mathrm{ng} / \mathrm{g}$. The highest levels of soot (about $8 \mathrm{ng} / \mathrm{g}$ ) were measured $2 \mathrm{~km}$ southeast of the Argentinian Esperanza Base $\left(63.4^{\circ} \mathrm{S}\right)$. BC decreased continuing south to the Palmer Archipelago; $\mathrm{BC}$ concentration generally ranged from 3 to $5 \mathrm{ng} / \mathrm{g}$ on Trinity Island $\left(63.9^{\circ} \mathrm{S}\right)$ but was generally lower than $2 \mathrm{ng} / \mathrm{g}$ on Doumer Island $\left(64.9^{\circ} \mathrm{S}\right)$. The low BC content in samples collected on Doumer Island (at sites close to the southernmost point of the island about $25 \mathrm{~km}$ east of the U.S. Palmer Station) approximately matches prior $\mathrm{BC}$ measurements conducted in the region $^{16}$. BC concentrations further decreased southward along the Antarctic Peninsula to a minimum at the southernmost sampling sites; BC concentration generally ranged from 1 to $2 \mathrm{ng} /$ g on Peterman Island $\left(65.2^{\circ} \mathrm{S}\right)$ and Detaille Island $\left(66.9^{\circ} \mathrm{S}\right)$, two popular tourist-landing sites but without permanent settlements.

Dust presence. A latitude dependence of absorption Ångström exponent $(\alpha)$ is less clear (Fig. 2c). This exponent characterizes spectral absorption properties of light-absorbing impurities in snow. The two most common light-absorbing particles are soot and crustal dust. Under most conditions, BC dominates light 
a

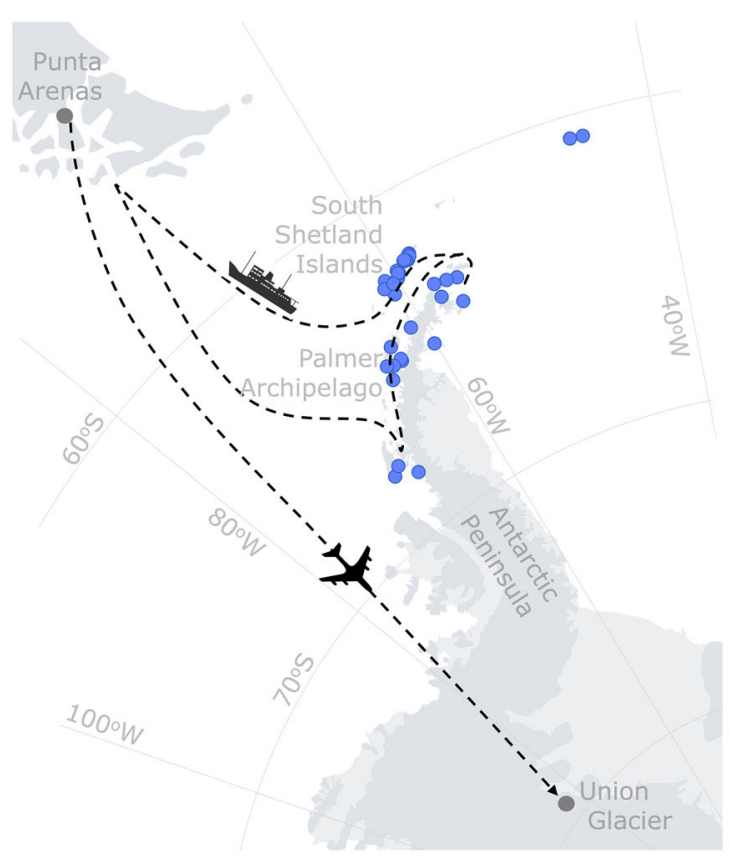

b

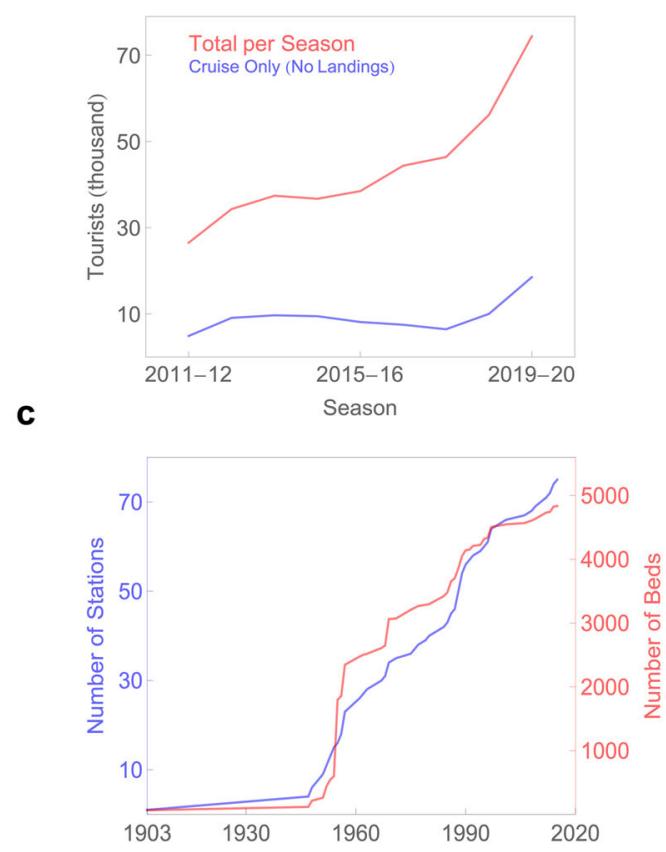

Fig. 1 Human presence in Antarctica has surged in recent decades. a Blue dots represent research stations in the area of interest according to the Council of Managers of National Antarctic Programs (COMNAP) ${ }^{33}$. Dotted lines represent popular tourist routes. Most of the visitors travelling to Antarctica with International Association of Antarctica Tour Operators (IAATO) embark on a ship for cruising the Antarctic Peninsula, where about half of the research facilities in the continent are located. Around 1\% of all visitors fly to the interior of Antarctica where they stay in field camps such as Union Glacier Camp. IAATO has now more than 50 operators whose fleet of 54 vessels (including 6 large cruise ships) registered a total of 378 departures in the 2019-2020 season ${ }^{36}$. b Visitors have been growing steadily since 2011-2012. Of the 74,401 visitors who travelled with IAATO members to the region, about $25 \%$ travelled on cruise-only vessels (i.e., vessels carrying more than 500 passengers) and did not set foot on the continent. c There are currently 76 research stations in Antarctica (including seasonal facilities) with a combined accommodation capacity (for both scientists and staff) of about five thousand beds ${ }^{33}$. There are 11 research stations (with a total of 700 beds) on King George Island only ${ }^{33}$. Plots were generated by using Python's Matplotlib Library 58 .

absorption since it has a mass absorption coefficient (MAC) that is several orders of magnitude greater than dust at visible wavelength ${ }^{18}$. For samples that contain both $\mathrm{BC}$ and dust, the Ångström exponent typically ranges from 1.1 (corresponding to pure $\mathrm{BC}$ ) to about 4 (corresponding to dust) ${ }^{10}$. How much $\alpha$ values deviate from 1.1 is an indication of the relative contribution of dust to light absorption. The fact that the absorption Ångström exponent of light-absorbing impurities in our samples ranged from 2 to 3 highlights the contribution of non-BC constituents to light absorption, especially on the Antarctic Peninsula. Most of the extensive Byers Peninsula (about $60 \mathrm{~km}^{2}$ ), forming the west extremity of Livingston Island (South Shetland Islands), is ice-free in summer; the same goes for the Ulu Peninsula (about $312 \mathrm{~km}^{2}$ ) in the northeastern Antarctic Peninsula region ${ }^{31}$. Ice-free areas in Antarctica have been shown to be an important source of dust ${ }^{31,32}$.

Statistical significance tests (Supplementary Fig. 2, Supplementary Tables 1-2) confirm that measurements of the BC concentration and the Ångström exponent at sites on the Antarctica Peninsula and associated archipelagos are significantly different from those taken at sites on Union Glacier (in the vast interior of the continent, $79^{\circ} \mathrm{S}$ ). Yet, even at these remote locations, both BC and dust deposition are present (Fig. 3). Union Glacier is the site of a blue-ice runway and two seasonally occupied camps (a Chilean camp and another operated by a private company). In addition to the blue-ice runway, both camps operate ski-equipped airplanes. These facilities dominate BC deposition in this region, while the ice-free summits of the surrounding Ellsworth Mountains are likely the source of most of the dust found in local snow. In samples taken from the surface, $6 \mathrm{~km}$ east of the blue-ice runway, BC concentration generally ranged from 1 to $3 \mathrm{ng} / \mathrm{g}$. These concentrations likely resulted from the fact that winds at Union Glacier predominantly come from the southwest, and roughly match prior BC measurements conducted downwind from the Amundsen-Scott station and its airfield ${ }^{18}$. The Ångström exponent from samples collected at Union Glacier ranged from 1 to 3 . These values are considerably lower than those from the Antarctic Peninsula, which is compatible with the fact that the Ellsworth Mountains are less dusty than the archipelagos off the Antarctic Peninsula.

A $2.6 \mathrm{~m}$ depth snowpit (Fig. 3b, c) enabled us to test potential year-to-year changes in the BC deposition on Union Glacier. BC concentration appears to have been decreasing in recent years from a maximum of about $3 \mathrm{ng} / \mathrm{g}$ during the 2013-2014 season (Fig. 3d), when the Chilean Union Glacier Camp became operational. The interannual changes in the absorption Ångström exponent (Fig. 3e) roughly followed (although in opposite direction) the changes in the $\mathrm{BC}$ concentrations (Fig. 3d). This suggests that changes in $\mathrm{BC}$ deposition drive year-to-year changes in light absorption while dust accumulation remains roughly constant. Since the Ångström exponent is an indicator of the relative contribution of dust to light absorption, it is plausible to attribute the peak during 2011-2012 to low BC deposition during that season (Fig. 3e).

Other light-absorbing impurities. The absorbing particles on the filters were not always a combination of $\mathrm{BC}$ and dust only, 


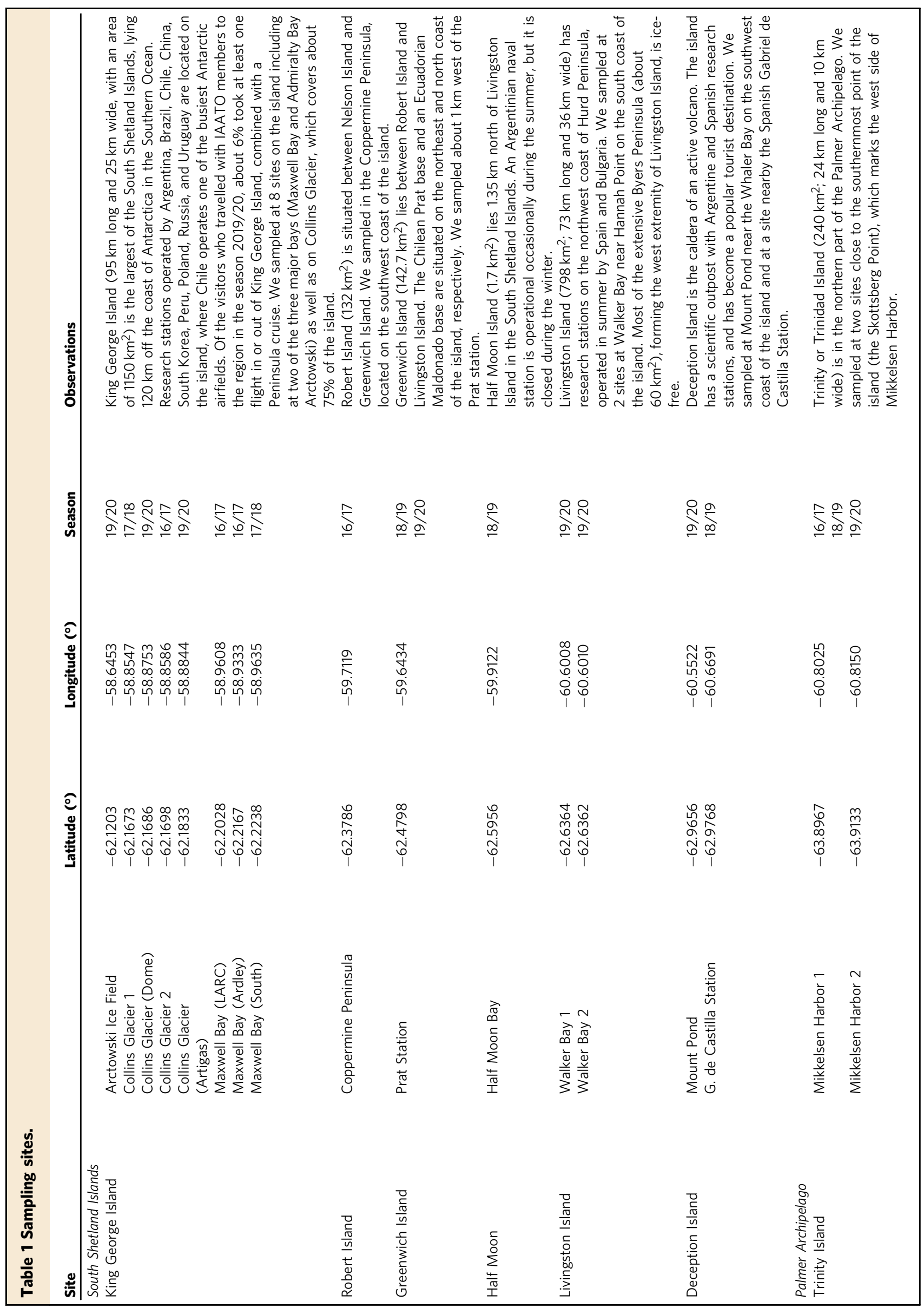


NATURE COMMUNICATIONS I https://doi.org/10.1038/541467-022-28560-w $\quad$ ARTICLE

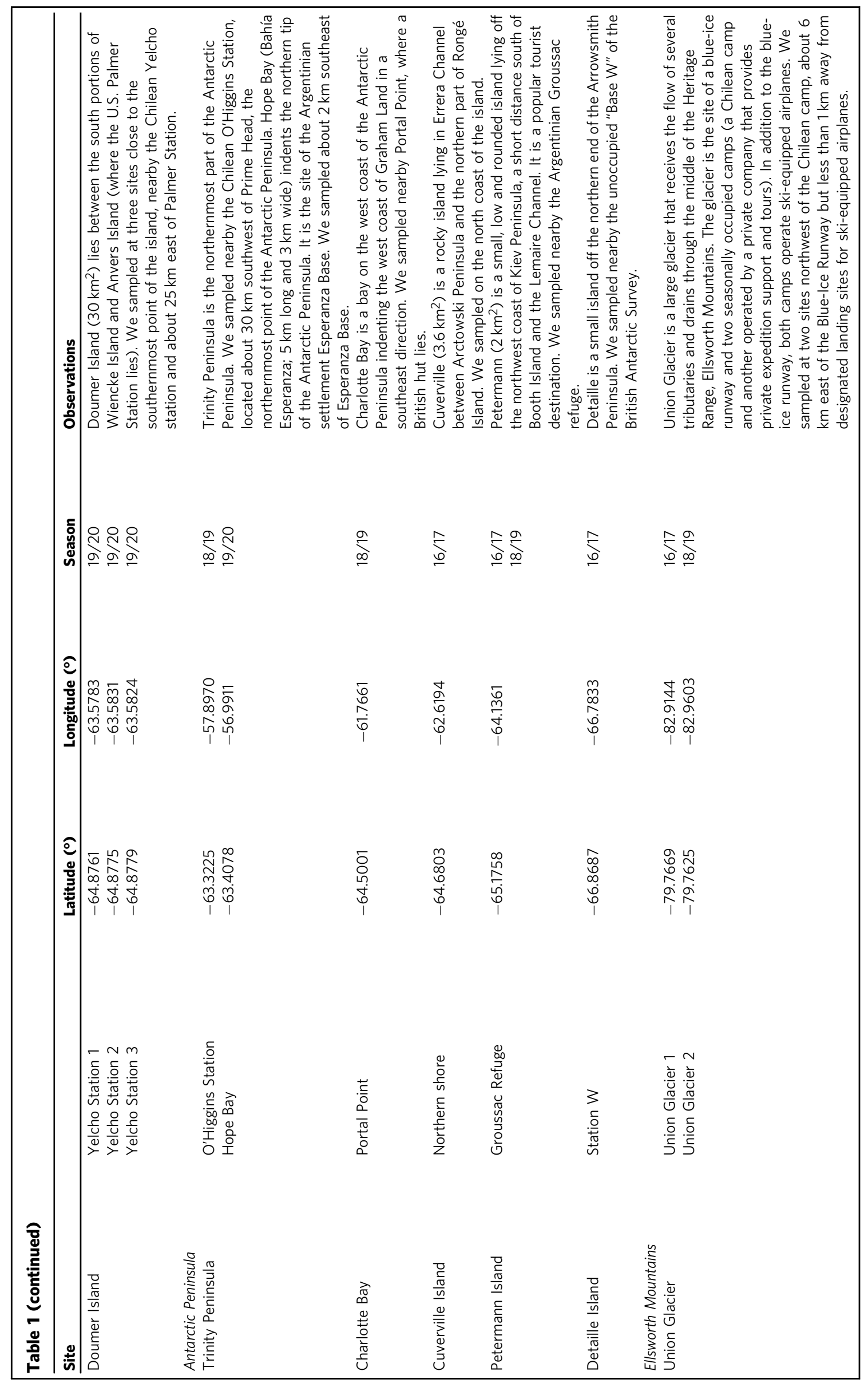

NATURE COMMUNICATIONS | (2022)13:984 | https://doi.org/10.1038/s41467-022-28560-w | www.nature.com/naturecommunications

5 
a

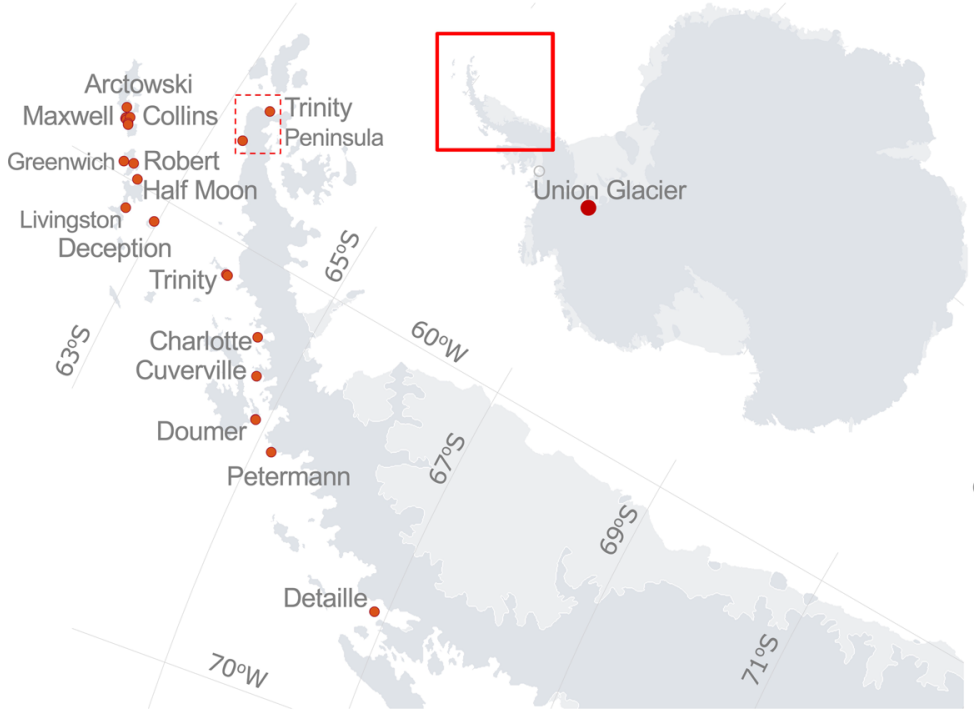

b

C

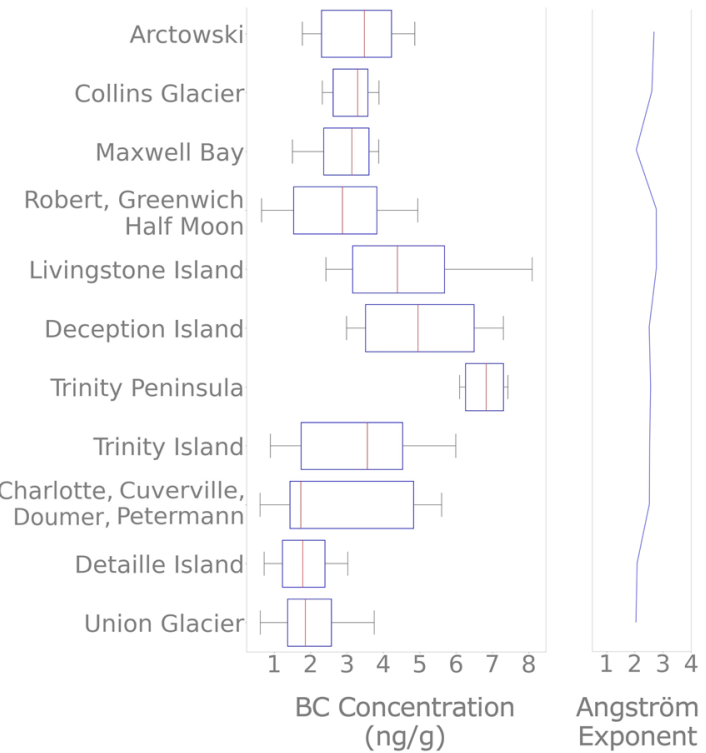

Fig. 2 Black Carbon (BC) concentration around research stations and popular tourism destinations is considerable higher than elsewhere in

Antarctica. a Red dots represent the snow sampling sites. We sampled at 15 sites on the South Shetland Islands (where 16 research stations are located), five sites in the Palmer Archipelago, six sites on or near the coast of the Antarctic Peninsula, and at two deep-field sites on Union Glacier (Ellsworth Mountains); see Table 1 for details. b Boxplots of the BC concentrations in samples from different locations. In each box, the central mark (red stripe) indicates the median, and the edges indicate the 25th and 75th percentiles. The whiskers extend to the maximum and minimum data excluding outliers. $\mathbf{c}$ Mean of the absorption Ångström exponent of light-absorbing impurities in samples from different locations. Locations, given in order of latitude, in plots $\mathbf{b}$ and $\mathbf{c}$, may combine samples from nearby sites. Measurements in plots $\mathbf{b}$ and $\mathbf{c}$ were subjected to the statistical significance tests whose results are presented in the Supplementary Information. Plots were generated by using Python's Matplotlib Library ${ }^{58}$.

especially on the Antarctic Peninsula and associated archipelagos where snow algae are abundant on or near the coast ${ }^{38}$. Since algae also absorb light, especially in the visible range ${ }^{39}$, we avoided sampling on algal fields (Supplementary Fig. 3a, b). Nevertheless, the distinctive presence of algal pigment appeared on the filters (Supplementary Fig. 3c) corresponding to some samples taken on Petermann Island, Robert Island, King George Island, and Doumer Island. The presence of algal biomass in snow from areas where it was not visible "to the naked eye" suggests that snow algae may be more abundant in Antarctica than prior estimates based on remote sensing ${ }^{38}$. It is apparent that the particulate absorption for the filters that exhibited vivid shades of red was strongly influenced by algal biomass. We used these samples for measuring the absorption optical properties of snow algae; we confirmed that light absorption attributable to algal biomass decreases rapidly with wavelength and plays no significant role in the absorption at wavelengths longer than $700 \mathrm{~nm}$ (which agrees with recent albedo measurements on algal fields ${ }^{39}$ ). The absorption Ångström exponent corresponding to samples with apparent algae presence ranged from 4 to 6 , which is generally above the values of the absorption Ångström exponent corresponding to samples without apparent algae presence (Supplementary Fig. 4).

Albedo reduction and snowmelt. It is likely that local emissions account for most of the $\mathrm{BC}$ content in samples collected around research facilities and popular shore tourist-landing sites. BC concentration measured on the Antarctic Peninsula and associated archipelagos generally ranged from 2 to $4 \mathrm{ng} / \mathrm{g}$, roughly corresponding to the 25th and 75th percentiles of samples collected in that region (Supplementary Table 3). These BC concentrations significantly exceed background levels $(\sim 1 \mathrm{ng} / \mathrm{g}$, Supplementary Table 4) and are hardly attributable to intercontinental transport. Although massive wildfires in Patagonia can enhance $\mathrm{BC}$ depositions on the Antarctic Peninsula (last occurring in $2015^{40}$ ), no major wildfire occurred in Patagonia over the period 2016-2020 (when our sampling campaigns occurred).

Although albedo reductions associated with the BC content in our snow samples are relatively low, any change in the extremely high albedo of Antarctic snow (Fig. 4a and Supplementary Fig. 5) affects the local radiative balance. In order to estimate albedo reductions attributable to local emissions, we adopted the parameterization proposed by Dang et al. ${ }^{41}$ that provides, as a function of the cloud fraction $(C F)$, estimates of the albedo reduction $(\triangle \mathrm{A})$ for a range of $\mathrm{BC}$ mass mixing ratios and snow grain radii $(r)$. Albedo reductions are generally favored by larger snow grains ${ }^{41}$ and by clouds ${ }^{4}$. Although the snow of grain radii may exhibit a considerable dispersion (from 200 to $600 \mu \mathrm{m}$ ), the cloud fraction is generally close to 1 on the Antarctic Peninsula and associated archipelagos, one of the cloudiest regions on Earth.

According to the formulation by Dang et al. ${ }^{41}$, the change in the $\mathrm{BC}$ concentrations attributable to local emissions on the Antarctic Peninsula and associated archipelagos can lead to albedo reductions ranging from 0.001 to 0.004 at $\mathrm{BC}$-impacted sites. The lower limit (0.001) corresponds approximately to the albedo reduction expected if the BC concentration in snow of grain radii $r=200 \mu \mathrm{m}$ changes from $1 \mathrm{ng} / \mathrm{g}$ (the background level) to $2 \mathrm{ng} / \mathrm{g}$ due to local emissions (Supplementary Fig. 6). The upper limit (0.004) corresponds approximately to the albedo reduction expected if the $\mathrm{BC}$ concentration in the snow of grain radii $r=600 \mu \mathrm{m}$ changes from $1 \mathrm{ng} / \mathrm{g}$ (the background level) to $4 \mathrm{ng} / \mathrm{g}$ due to local emissions (Supplementary Fig. 6). Since the summer shortwave solar irradiance is on average about $250 \mathrm{~W} / \mathrm{m}^{2}$ on the Antarctic Peninsula and associated archipelagos (Fig. 4b), albedo reductions over the range $0.001-0.004$ would lead to a positive local forcing of $0.25-1.00 \mathrm{~W} / \mathrm{m}^{2}$, which is comparable to the perturbation caused by the accumulation of some greenhouse gases in the atmosphere in recent decades. 
a

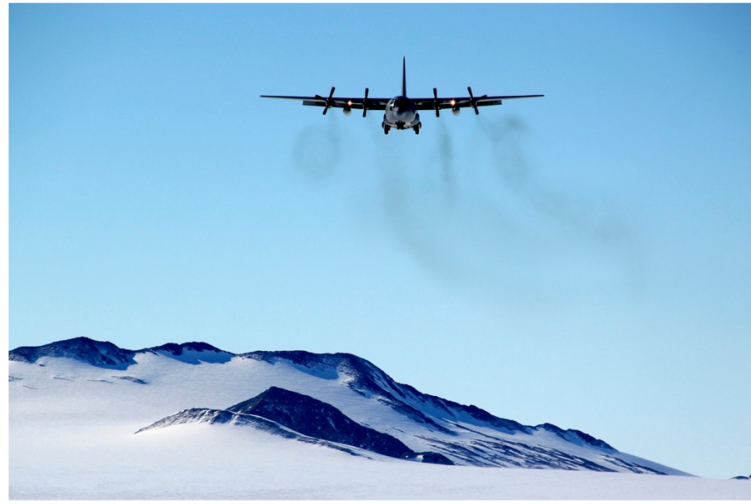

b

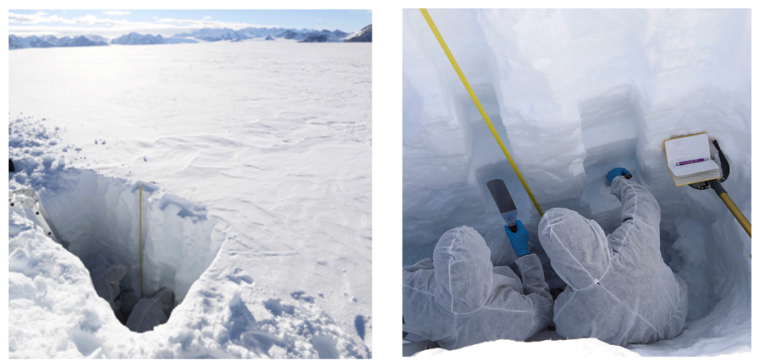

d

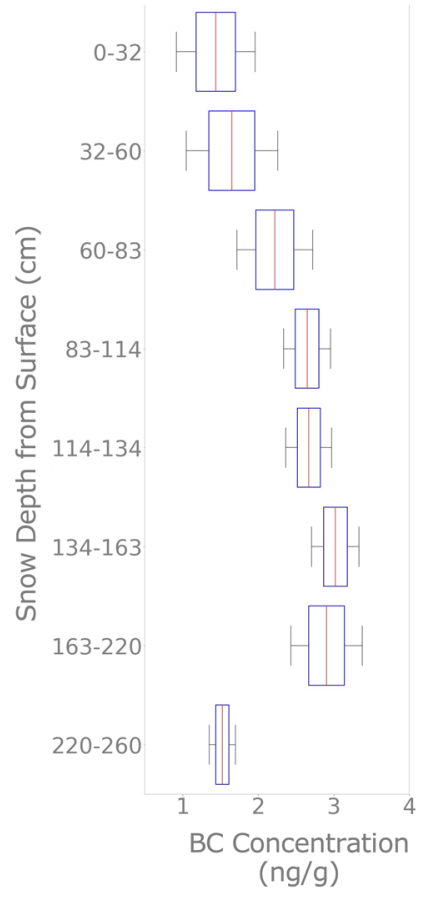

e

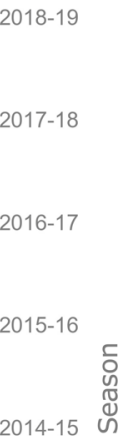

2013-14

2012-13

2011-12

$\begin{array}{lllll}1 & 2 & 3 & 4\end{array}$

Angström

Exponent

Fig. 3 Black Carbon (BC) concentration is above background levels even around deep-field tourist destinations. a C-130 aircraft about to land on the blue-ice runway at Union Glacier ( $79^{\circ} \mathrm{S}$, Ellsworth Mountains), an increasingly popular deep-field destination (a private four-engine turbofan Ilyushin II-76 landed on the runway 30 times in the 2019-2020 season only ${ }^{34}$ ). b, c Snowpit for snow sampling ( $6 \mathrm{~km}$ east of the blue-ice runway and about $1 \mathrm{~km}$ west of the designed landing sites for ski-equipped airplanes). d BC concentrations measured at different snow layers. BC concentration peaked at about $3 \mathrm{ng} / \mathrm{g}$ during the 2013-2014 season. Although private activities began years earlier, the Chilean Union Glacier Camp became operational during the 2013-2014 season. In each box, the central mark (red stripe) indicates the median, and the edges indicate the 25th and 75th percentiles. The whiskers extend to the maximum and minimum data excluding outliers. e Mean of the absorption Ångström exponent of light-absorbing impurities in snow from different layers. Photographs taken by the authors. Plots were generated by using Python's Matplotlib Library ${ }^{58}$.

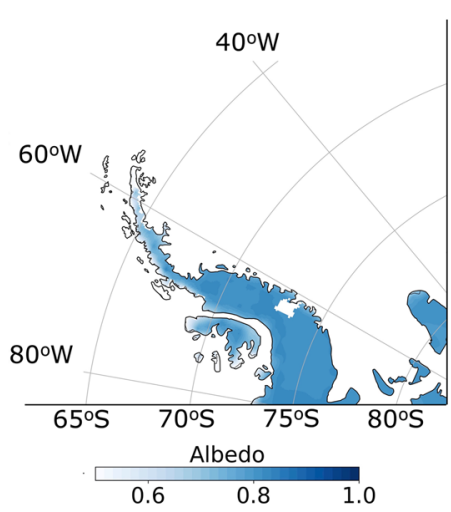

b

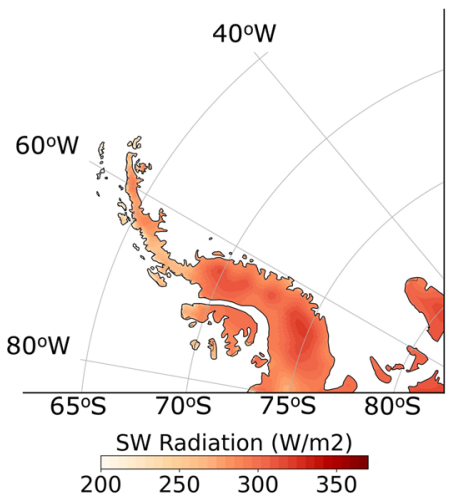

c

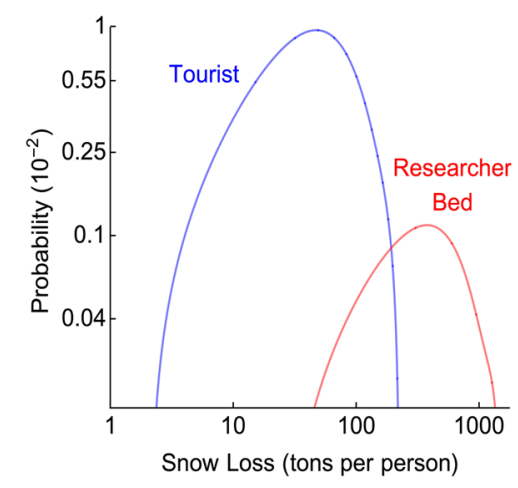

Fig. 4 Black Carbon (BC) from local activities in Antarctica darkens the snow and makes it melt sooner. a Broadband shortwave (SW) albedo averaged for December, January and February (DJF) days over the period 2004-2020. Data from MERRA-254 were used. b Downwelling shortwave (SW) all-sky irradiance averaged for DJF days over the period 1981-2019. The all-sky DJF SW irradiance is about $250 \mathrm{~W} / \mathrm{m}^{2}$. Data from the ERA5 Atmospheric Reanalysis ${ }^{46}$ were used. c Probability density function of the snow that melts sooner due to the BC footprint of a researcher (red line) and a tourist (blue line). These probabilities are based on the simulations shown in Supplementary Figs. 7-8. In the case of the snow that melts sooner due to the BC footprint attributable to a researcher, we assumed that the area impacted by the presence of 11 research stations (with a total of 700 beds ${ }^{33}$ ) on King George Island ranges from 6 to $48 \mathrm{~km}^{2}$. In the case of the snow that melts sooner due to the $\mathrm{BC}$ footprint attributable to a tourist, we assumed that the area impacted by $B C$ emissions related to tourism ranges from 100 to $500 \mathrm{~km}^{2}$; we also considered that, on average, 53,000 tourists visited Antarctica annually from season 2016-2017 to the season 2019-202036. Plots were generated by using Python's Matplotlib Library58.

The positive forcing attributable to both research and tourism in Antarctica is accelerating snowmelt in BC-impacted areas (i.e., the snow-covered area where $\mathrm{BC}$ deposition occurred). We estimate that seasonal snow that melts sooner every summer at
BC-impacted sites due to the associated albedo reduction ranges from 5 to $23 \mathrm{~kg} / \mathrm{m}^{2}$ (see Methods). This is equivalent to a snowpack shrinking of up to $23 \mathrm{~mm}$ w.e. The total mass loss attributable to the albedo reduction depends on how large the 
BC-impacted area is. The latter is ultimately determined by how representative our snow samples are. Although limited spatial and temporal sampling could compromise our estimates, we can provide lower limits of snow mass loss assuming plausible values for the BC-impacted areas.

On King George Island, the largest of the South Shetland Islands, the snow that melts sooner every summer due to the $\mathrm{BC}$ footprint (largely attributable to research stations) is estimated to be $0.4 \pm 0.2 \mathrm{Mt}$. We arrived at this figure by assuming that the $\mathrm{BC}$ concentration measured at each site is representative of a surrounding surface that ranged from 1 to $6 \mathrm{~km}^{2}$. We sampled at 8 sites on King George Island such that we indirectly assumed that the BC-impacted area on King George Island was at most $48 \mathrm{~km}^{2}(8 \times 6)$, which is equivalent to $4 \%$ of the island's surface. This is a conservative estimation since King George is likely one of the most impacted islands in Antarctica. Research stations operated by Argentina, Brazil, Chile, China, South Korea, Peru, Poland, Russia, and Uruguay are located on the island, where Chile operates one of the busiest Antarctic airfields. According to COMNAP ${ }^{33}$, there are eleven research stations on King George Island with a total of 700 beds, which means that the BC attributable to bed/researcher on the island accelerates melting of $0.6 \pm 0.3 \mathrm{kt}$ of snow every season (Fig. $4 \mathrm{c}$ ).

Moreover, we estimate that the snow that melts sooner every summer due to the $\mathrm{BC}$ footprint of tourism on the Antarctica Peninsula and associated archipelagos is $4.4 \pm 2.3 \mathrm{Mt}$. We arrived at this value by assuming that the area impacted by tourism ranges from 100 to $500 \mathrm{~km}^{2}$ (note that $500 \mathrm{~km}^{2}$ is around $0.1 \%$ of the surface of the Antarctic Peninsula and associated archipelagos). An average of 53,000 visitors travelled to Antarctica with IAATO operators from the season 2016-2017 to the season 2019-2020, which means that the BC attributable to an average visitor may accelerate summer melting of $83 \pm 43$ tons of snow (Fig. 4c).

\section{Discussion}

Our systematic efforts to quantify the BC impact of local activities in Antarctica have revealed the burdens of $\mathrm{BC}$ deposition attributable to human activities (research activities and tourism) in the most visited region of the continent. Our surveys have shown that BC content in snow surrounding research facilities and popular shore tourist-landing sites ( 2 to $4 \mathrm{ng} / \mathrm{g}$ ), while well below $\mathrm{BC}$ concentrations typical of other remote regions, is considerably above background levels measured elsewhere in the continent $(\sim 1 \mathrm{ng} / \mathrm{g})$.

The radiative forcing owing to measured $\mathrm{BC}$ concentration is accelerating snowmelt and shrinking the snowpack of BCimpacted areas of the Antarctic Peninsula and associated archipelagos by up to $23 \mathrm{~mm}$ w.e. every summer. Burdens of $\mathrm{BC}$ deposition varied geographically, but we estimate that premature snowmelt due to the $\mathrm{BC}$ footprint of tourism is on the order of dozens to hundreds of tons per visitor (Fig. 4c). The intensive use of fuel-powered equipment at scientific stations makes the average snow losses attributable to each researcher at least one order of magnitude higher (Fig. 4c).

The $\mathrm{BC}$ footprint of research activities has likely increased as the construction of new facilities has risen in Antarctica. In recent years, there have been many new infrastructure projects on the Peninsula and associated archipelagos. For example, Brazil reconstructed its research station doubling its size, while the United Kingdom expanded the footprint of its Rothera station. Prior research has shown that buildings and infrastructure associated with science facilities displace wildlife and vegetation. Here, we have shown that research activities-which often include the use of helicopters, watercraft, airplanes, diesel generators, and all- terrain vehicles-are considerably darkening snow-covered areas next to research stations.

The BC footprint of tourism is likely driven by cruise emissions. A typical cruise includes several shore landings at the sites where we sampled. Cruise routes operated by IAATO often include exploring the volcanic islands of the South Shetland Islands and the Palmer Archipelago as well as visiting small islands off the Antarctic Peninsula such as Cuverville $\left(64^{\circ} \mathrm{S}\right)$, Petermann $\left(65^{\circ} \mathrm{S}\right)$ and Detaille $\left(67^{\circ} \mathrm{S}\right)$. IAATO has been gaining an average of two to five operators every year and now includes more than 50 operators whose fleet of 54 vessels (including 6 large cruise ships) conducted a total of 378 departures in the 2019-2020 season ${ }^{36}$.

The BC footprint per tourist was likely larger a decade ago, before the International Maritime Organization (IMO) banned the use of heavy fuel. Moreover, following IAATO advocacy for safe and environmentally responsible travel, some positive steps have been taken. Ships in Antarctica generally use less-polluting marine diesel, and some vessels are supplementing fuel with battery power. Nevertheless, our results show that more remains to be done to reduce the impacts of tourism and ships in Antarctica; otherwise, the burdens of BC deposition attributable to tourism will likely increase as human presence in Antarctica increases further.

Mechanisms to mitigate BC impacts are needed. IAATO should limit tourist activity and continue to push for a faster transition to clean fuel and hybrid or electric ships, while COMNAP should encourage National Antarctic Programs to limit the size and footprints of their research sites in Antarctica. Widespread adoption of energy efficiency standards and renewable power plants are urgently needed to limit the BC footprint of research facilities in Antarctica.

\section{Methods}

Sample collection and filtration. Surveys were conducted during four consecutive seasons, from 2016-2017 to 2019-2020. We sampled at a total of 28 sites across a transect of about $2000 \mathrm{~km}$ from the northern tip of Antarctica (King George Island, $62^{\circ} \mathrm{S}$ ) to the southern Ellsworth Mountains (Union Glacier Camp, $79^{\circ} \mathrm{S}$ ); see Table 1 for further details.

Sampling was generally carried out in late summer, at the end of the melt season, mostly at coastal sites where the snow is often thin and patchy. Union Glacier was an exception; at this deep-field location, sampling occurred in early December. BC concentration in snow samples collected in late summer are expected to be the highest of the season since particles collect at the surface as the snow melts during summer; ${ }^{42} \mathrm{BC}$ normally concentrates at the surface in melting snow and only $10-30 \%$ of the BC is removed with meltwater ${ }^{43}$. We focused on summer because $\mathrm{BC}$ deposition in seasons other than summer is not consequential in terms of snowmelt or radiative balance.

We collected duplicates from the snow-covered surfaces, horizontally separated by around $1 \mathrm{~m}$. The difference between these measurements was generally lower than $1 \mathrm{ng} / \mathrm{g}$ but we did occasionally find differences slightly higher than $1 \mathrm{ng} / \mathrm{g}$. These differences may have resulted from actual variations in the BC content as soot content in Antarctica may vary considerably on horizontal scales of a few meters due to frequent blizzards ${ }^{18}$. At four sites on the Antarctica Peninsula, where the snow was abundant enough, snow was sampled vertically at intervals of $10-20 \mathrm{~cm}$ depth to study the vertical distribution of BC in snowpits that captured the entire snowpack (up to $1 \mathrm{~m}$ depth from the surface). In some cases, the surface layer was cleaner than the subsurface layers, which is likely due to snowdrift or recent precipitation. However, $\mathrm{BC}$ concentrations were found to be generally comparable within a profile (of the same order). At Union Glacier Camp, a deeper snowpit (up to $2.6 \mathrm{~m}$ depth) enabled us to test potential year-to-year changes in the $\mathrm{BC}$ concentration. The masses of samples ranged from 1 to $2 \mathrm{~kg}$ each.

As our aim was to assess the influence of light-absorbing impurities on the albedo of representative areas, sampling sites were chosen to always be hundreds of meters (even kilometers when possible) away from apparent pollution sources such as research stations, tourist shore landings, roads and airfields. Moreover, particular attention was paid to preventing contamination of the samples. A stainless-steel spatula was used for collection and samples were placed into plastic bags, which were in turn packed in Whirlpack bags. Styrofoam coolers were used for transportation to the laboratory. In the laboratory deionized water was used to wash tools and containers before filtering, and latex gloves and lab coats were worn during filtering. Snow samples were transferred to a glass beaker and snowmelt was subsequently vacuum-filtered, leaving the insoluble material on the filter. Stainless- 
steel funnels and $0.4 \mu \mathrm{m}$ Nucleopore filters were used. Filters were subsequently placed in sterile petri dishes. Our field blank analyses showed that the effect of contamination during the sampling, storage and transportation was on the order of tenths of $\mathrm{ng} / \mathrm{g}$

BC concentration and Ångström exponent. We applied the Meltwater Filtration (MF) Technique, initially proposed by Clarke and Noone ${ }^{7}$, that has been broadly applied for measuring BC concentrations in snow samples from around the world (from the Arctic ${ }^{4-7}$, North America ${ }^{8,9}$, Northern China ${ }^{10}$, the Andes ${ }^{13}$, and the South Pole $\left.^{18}\right)$. The MF technique's measures of absorption are closely related to the sunlight absorption in the snowpack ${ }^{44}$.

Following the procedure described by Grenfell et al. ${ }^{44}$, filters were analyzed for light transmission. We measured over the range $340-750 \mathrm{~nm}$ at a $5 \mathrm{~nm}$ resolution using a spectrophotometer. These measurements were used to derive the maximum possible $\mathrm{BC}$ concentration $\left(C_{\mathrm{MAX}}\right)$, the best estimate of the $\mathrm{BC}$ concentration $\left(C_{\mathrm{EST}}\right)$, and the spectral absorption properties of light-absorbing particles in samples (i.e., the Ångström exponent).

Spectrophotometric measurements allowed us to compute the absorbance $(A)$ taken as equal to the inverse of the logarithm of the transmittance $(T)$ of the spectral radiant power through the filters:

$$
A=-\log T \text {. }
$$

The absorbance at each wavelength over the range $340-750 \mathrm{~nm}$ was then converted to a BC-equivalent loading $(L)$ by using wavelength-dependent calibration curves. These calibration curves were previously obtained from measurements of the light transmission through filters loaded with known amounts of synthetic Monarch-71 soot, often taken as a proxy for BC in nature. A comparison of the light attenuation by a sample filter to the light attenuation by the synthetic standards yields the $\mathrm{BC}$-equivalent loading of the sample filter. The wavelength-dependent BC-equivalent loading $(L)$ was then converted to a BCequivalent concentration $(C)$ by accounting for the filter-exposed area $(S)$ and the mass of snow meltwater from each sample $(V)$ :

$$
C=L \cdot \frac{S}{V} \text {. }
$$

The BC-equivalent concentration generally varies with wavelength because the sample filter usually contains non-BC light-absorbing particles as well as BC particles, whose spectral responses differ. However, absorption by non-BC constituents decreases more rapidly with wavelength than does absorption by BC. Accordingly, both dust ${ }^{45}$ and alga ${ }^{39}$ play no significant role in the absorption at wavelengths longer than $700 \mathrm{~nm}$ and concentrations computed by Eq. (2) exhibit few changes over the range $700-750 \mathrm{~nm}$.

Since most of the light absorption observed over the range $700-750 \mathrm{~nm}$ is attributable to $\mathrm{BC}$, here we estimated the maximum possible $\mathrm{BC}$ concentration $\left(C_{\mathrm{MAX}}\right)$ for each sample by averaging the wavelength-dependent concentration computed by Eq. (2) over the range $700-750 \mathrm{~nm}$.

The spectral absorption properties of light-absorbing impurities in samples can be characterized by fitting the absorption Ångström law to the wavelengthdependent absorption optical depth (AOD):

$$
\operatorname{AOD}(\lambda)=\beta \cdot \lambda^{-\alpha},
$$

where $\lambda$ is the wavelength in $\mu \mathrm{m}$, and $\alpha$ and $\beta$ are referred to as Ångström parameters. At each wavelength over the range $340-750 \mathrm{~nm}$, the AOD is the mass absorption coefficient (MAC) of Monarch-71 soot multiplied by the BC-equivalent loading $(L)$. MAC estimates of fullerene are $9.8 \mathrm{~m}^{2} / \mathrm{g}$ at $400 \mathrm{~nm}, 7.2 \mathrm{~m} / \mathrm{g}$ at $550 \mathrm{~nm}$, and $5.9 \mathrm{~m}^{2} / \mathrm{g}$ at $650 \mathrm{~nm}^{8}$. According to Eq. (3), the absorption Ångström exponent $(\alpha)$ was calculated for each sample as a linear fit over the range $420-620 \mathrm{~nm}$ to the plot AOD- $\lambda$ in $\log -\log$ space. Prior efforts ${ }^{6,43}$ have shown that the absorption Angström exponent of pure $\mathrm{BC}\left(\alpha_{\mathrm{BC}}\right)$ is 1.1. The deviation of the absorption Ångström exponent from 1.1 is, therefore, an indication of the amount of absorption by non-BC particles in the snow.

Calculation of the best estimate of the $\mathrm{BC}$ concentration $\left(C_{\mathrm{EST}}\right)$ in samples requires attribution of total measured absorption to $\mathrm{BC}$ and non- $\mathrm{BC}$ constituents. In order to separate the absorption contributions, we followed Grenfell et al ${ }^{43}$ expanding the absorption Angström exponent $(\alpha)$ around the midpoint $\left(\lambda_{o}=\right.$ $520 \mathrm{~nm}$ ) of the range $340-700 \mathrm{~nm}$ :

$$
\alpha=z \cdot \alpha_{\mathrm{BC}}+(1-z) \cdot \alpha_{\mathrm{NBC}},
$$

where $z$ stands for the fraction of absorption due to BC in samples, $\alpha_{\mathrm{BC}}=1.1$, and $\alpha_{\mathrm{NBC}}$ is the Ångström exponent of non-BC light-absorbing particles (i.e., crustal dust) that, according to prior research ${ }^{10}$, we took equal to 4 . Rearranging Eq. (4) yields $z$, which can, in turn, be used to compute $\mathrm{AOD}_{\mathrm{BC}}$ at $\lambda_{o}=520 \mathrm{~nm}$ :

$$
\operatorname{AOD}_{\mathrm{BC}}\left(\lambda_{o}\right)=z \cdot \operatorname{AOD}\left(\lambda_{o}\right),
$$

where $\operatorname{AOD}\left(\lambda_{o}\right)$ is the MAC of Monarch-71 soot multiplied by the BC-equivalent loading $(L)$ at $\lambda_{o}=520 \mathrm{~nm}$. $\mathrm{AOD}_{\mathrm{BC}}(\lambda)$ is related to the Ångström exponent of pure $\mathrm{BC}\left(\alpha_{\mathrm{BC}}\right)$ by the absorption Ångström law:

$$
\operatorname{AOD}_{\mathrm{BC}}(\lambda)=\beta \cdot \lambda^{-\alpha_{\mathrm{BC}}},
$$

where $\beta$ can be written as a function of the $\operatorname{AOD}\left(\lambda_{o}\right)$ by rearranging the Ångström law:

$$
\beta=\operatorname{AOD}_{\mathrm{BC}}\left(\lambda_{o}\right) \cdot \lambda_{o}{ }^{\alpha_{\mathrm{BC}}} .
$$

The wavelength-dependent absorption optical depth corresponding to the $\mathrm{BC}$ in samples was estimated by combining Eqs. (6) and (7):

$$
\operatorname{AOD}_{\mathrm{BC}}(\lambda)=\operatorname{AOD}_{\mathrm{BC}}\left(\lambda_{o}\right) \cdot\left(\frac{\lambda}{\lambda_{o}}\right)^{-\alpha_{\mathrm{BC}}} .
$$

Finally, since the absorption over the range $700-750 \mathrm{~nm}$ is attributable to $\mathrm{BC}$, we computed the best estimate of the $\mathrm{BC}$ concentration $\left(C_{\mathrm{EST}}\right)$ in each sample according to

$$
C_{\mathrm{EST}}=C_{\mathrm{MAX}} \cdot\left(\frac{\mathrm{AOD}_{B C}(700: 750 \mathrm{~nm})}{\operatorname{AOD}(700: 750 \mathrm{~nm})}\right),
$$

where

$\mathrm{AOD}_{B C}(700: 750 \mathrm{~nm})$ is the average of $\mathrm{AOD}_{B C}$ values computed by Eq. (8) over the range $700-750 \mathrm{~nm}$, and

$\operatorname{AOD}(700: 750 \mathrm{~nm})$ is the average of the AOD values computed over the range $700-750 \mathrm{~nm}$.

Values of the Absorption Ångström exponent $(\alpha)$ and BC concentrations $\left(C_{\mathrm{EST}}\right)$ were used to build up Fig. 2. Details on the statistical significance of the data in Fig. 2 are shown in the Supplementary Information (Supplementary Tables 1-2).

Albedo reduction, radiative forcing, and snowmelt. According to Dang et al. ${ }^{4}$, the all-sky broadband albedo reduction $(\triangle A)$ due to light-absorbing impurities in snow can be estimated as

$$
\triangle A=C F \cdot \triangle A_{\text {cloudy }}+(1-C F) \cdot \triangle A_{\text {clear }},
$$

where $C F$ is the cloud fraction and $\triangle A_{\text {cloudy }}$ and $\triangle A_{\text {clear }}$ are the albedo reductions under overcast and cloudless conditions, respectively. Dang et al. ${ }^{41}$ provide estimates of both $\triangle A_{\text {cloudy }}$ and $\triangle A_{\text {clear }}$ for a range of $\mathrm{BC}$ mass mixing ratios and snow grain radii (Supplementary Fig. 6). Albedo reductions were not calculated for every site, but rather for regional averages.

The radiative forcing for summer months (DJF) was calculated as the albedo reduction times the all-sky shortwave irradiance $(I)$. For both $I$ and $C F$, we used estimates for summer months (DJF) from the ERA5 Atmospheric Reanalysis ${ }^{46}$ over the period 1981-2019, averaged over the region of interest. For the Antarctic Peninsula and associated archipelagos, one of the cloudiest regions on Earth, $I$ is typically about $250 \mathrm{~W} / \mathrm{m}^{2}$ (Fig. 4b) while $C F$ approaches 1 (Supplementary Fig. 7), such that and Eq. (10) reduces to:

$$
\triangle A=\triangle A_{\text {cloudy }} .
$$

The snow $(W)$ that melts sooner per unit of the surface due to the albedo reduction $(\triangle A)$ during summer in that region was estimated according to

$$
W=\frac{\triangle A . I . d}{E},
$$

where $d$ is a period of interest (that we took equal to the $90 \mathrm{DJF}$ days) and $E$ is the energy needed to melt $1 \mathrm{~kg}$ of snow (which we took to be equal to the latent heat of fusion, $334 \mathrm{~kJ} / \mathrm{kg}^{47}$ ).

Finally, the mass of the snow $\left(W_{t}\right)$ that melted sooner due to the albedo reduction $(\triangle A)$ associated to local emissions was estimated as

$$
W_{t}=\frac{\triangle A . I . d}{E} \cdot D,
$$

where $D$ is the $\mathrm{BC}$-impacted area (i.e., the snow-covered area where $\mathrm{BC}$ deposition occurred).

Snowmelt estimation for BC-impacted sites on the Antarctic Peninsula. We applied Eq. (12) and Eq. (13) to estimate the snowmelt attributable to the local BC emission, which first required estimating the albedo reduction $(\triangle A)$ associated with the $\mathrm{BC}$ content detected in samples collected around research stations and popular shore tourist-landing sites on the Antarctic Peninsula and associated archipelagos.

The albedo reduction $(\Delta A)$ depends on the cloud fraction $(C F)$, the snow grain radii $(r)$, and the $\mathrm{BC}$ concentration $\left(C_{\mathrm{EST}}\right)$. While the cloud fraction over the Antarctic Peninsula and associated archipelagos is generally close to 1 , the snow grain radii are strongly influenced by the temperature and may exhibit a considerable dispersion (from 200 to $600 \mu \mathrm{m}$ ). So does the BC concentration; our results show that the $\mathrm{BC}$ content detected in samples collected around research facilities and tourist-landing sites generally ranged from 2 to $4 \mathrm{ng} / \mathrm{g}$ (roughly corresponding to the 25th and 75th percentiles of samples collected on the Antarctic Peninsula and associated archipelagos; Supplementary Table 3).

According to the formulation by Dang et al. ${ }^{41}$ and considering the predominantly overcast conditions in our region of interest, the change in the $\mathrm{BC}$ concentrations attributable to local emissions can lead to albedo reductions over the range $0.001-0.004$ at $\mathrm{BC}$-impacted sites. The lower limit $(0.001)$ corresponds approximately to the albedo reduction expected if the $\mathrm{BC}$ concentration in the snow of grain radii $r=200 \mu \mathrm{m}$ changes from $1 \mathrm{ng} / \mathrm{g}$ (the background level) to $2 \mathrm{ng} / \mathrm{g}$ due to local emissions (see Supplementary Fig. 6a). The upper limit $(0.004)$ 
corresponds approximately to the albedo reduction expected if the $\mathrm{BC}$ concentration in the snow of grain radii $r=600 \mu \mathrm{m}$ changes from $1 \mathrm{ng} / \mathrm{g}$ (the background level) to $4 \mathrm{ng} / \mathrm{g}$ due to local emissions (see Supplementary Fig. 6a).

Since the summer shortwave solar irradiance is on average about $250 \mathrm{~W} / \mathrm{m}^{2}$ in the region (Fig. $4 \mathrm{~b}$ ), albedo reductions over the range $0.001-0.004$ would lead to a positive local forcing of $0.25-1.00 \mathrm{~W} / \mathrm{m}^{2}$, which will, in turn, make the local snowpack absorb on average an extra of $2-8 \mathrm{MJ} / \mathrm{m} 2$ over the 90 -day summer period. The enormous amount of extra energy absorbed by the snowpack will melt not only the snow at the zero-degree isotherm but also at sites where the air temperature is slightly below $0{ }^{\circ} \mathrm{C}$.

Equation (12) allowed to estimate the snow $(W)$ that melts sooner per unit of the surface at BC-impacted sites on the Antarctic Peninsula and associated archipelagos. Considering again that the summer shortwave solar irradiance is on average about $250 \mathrm{~W} / \mathrm{m}^{2}$ in our region (Fig. 4b), we found that albedo reductions over the range $0.001-0.004$ would lead to the snowmelt of $5-23 \mathrm{~kg} / \mathrm{m}^{2}$ (which is equivalent to a snowpack shrinking over the range $5-23 \mathrm{~mm}$ w.e.) over the 90 -day summer period.

We applied Eq. (13) to estimate the mass of the snow $\left(W_{t}\right)$ that melted sooner due to the albedo reduction $(\triangle A)$ associated with local emissions. The total mass loss attributable to the albedo reduction depends on how large the BC-impacted area $(D)$ is. The $\mathrm{BC}$-impacted area can range from a few square kilometers to dozens of square kilometers around a BC source. In the case of King George Island, we assumed that the BC-impacted area ranges from 6 to $48 \mathrm{~km}^{2}$ (about $0.7-4 \%$ of the island's surface). In the case of the area impacted by tourism, we assumed that it ranges from 100 to $500 \mathrm{~km}^{2}$ (around $0.02-0.10 \%$ of the surface of the Antarctic Peninsula and associated archipelagos).

In order to account for the effect of the dispersion of both $\triangle A$ and $D$, we conducted a Monte Carlo simulation ${ }^{48,49}$. Accordingly, we recursively applied Eq. (13) by using large sets of previously generated values of $\triangle A$ and $D$. In the case of King George Island, we randomly generated values of $\triangle A$ and $D$ over the ranges 0.001-0.004 and 8-48 $\mathrm{km}^{2}$, respectively (Supplementary Fig. 8). In the case of the area impacted by tourism, we randomly generated values of $\triangle A$ and $D$ over the ranges $0.001-0.004$ and $100-500 \mathrm{~km}^{2}$, respectively (Supplementary Fig. 9). Pairs of these randomly generated values were used as inputs in Eq. (13). The histograms of the results are shown in Supplementary Fig. $8 \mathrm{c}$ and Supplementary Fig. 9c. The mean and the standard deviations of the $W_{t}$ values in Supplementary Fig. 8c were used for estimating the snow that melts sooner every summer due to BC deposition from local sources on King George Island: $0.4 \pm 0.2 \mathrm{Mt}$, which translates to about $0.6 \pm 0.3 \mathrm{kt}$ of snow per bed; there are 11 research stations with a total of 700 beds on King George Island ${ }^{33}$. Similarly, the mean and the standard deviations of the $W_{t}$ values in Supplementary Fig. 9c were used for estimating the snow that melts sooner every summer due to BC emissions associated with tourism on the Antarctic Peninsula and associated archipelagos: $4.4 \pm 2.3 \mathrm{Mt}$, which translates to about $83 \pm 43$ tons per visitor; an average of 53,000 tourists visited the region from the season 2016-2017 to the season 2019-2020 36 .

Finally, we used the histograms shown in Supplementary Fig. $8 \mathrm{c}$ and Supplementary Fig. 9c to infer the probability density functions (Fig. 4c) of the snow that melts sooner due to the $\mathrm{BC}$ footprint of a researcher bed and a tourist. Figure $4 \mathrm{c}$ shows that the $\mathrm{BC}$ footprint of tourism in Antarctica is on the order of dozens to hundreds of tons per visitor (blue line); the intensive use of fuel-powered equipment at scientific stations makes average snow losses attributable to each researcher in Antarctica at least one order of magnitude larger (red line).

Back-trajectory analysis. Back-trajectory analysis suggests that long-range transport (from Patagonia for example) has only a minor role as a source of absorbing aerosols in Antarctica. We applied air-parcel backward trajectories to selected sampling sites. We used the Hybrid Single-Particle Lagrangian Integrated Trajectory (HYSPLIT) model ${ }^{50,51}$ fed with the Global Data Assimilation System (GDAS) archive (available in a resolution of three hours and a $1^{\circ}$ latitudelongitude $)^{52}$. For selected sites, we computed $72 \mathrm{~h}$ backward trajectories for DJF days over the period 2010-2020 (Supplementary Fig. 10). For the same sites, we separately computed $72 \mathrm{~h}$ backward trajectories for a 3-month period before sampling (Supplementary Fig. 11). These trajectories were divided into clusters following a cluster analysis based on the total spatial variance (TSV) ${ }^{53}$. The results, shown in the Supplement Information for 4 representative sampling sites, support the premise of this work: most of the $\mathrm{BC}$ in our samples was emitted locally.

Reanalysis. Broadband shortwave (SW) albedo data were obtained over the period 2004-2020 from Modern-Era Retrospective analysis for Research and Applications (MERRA-2) ${ }^{54}$. Downwelling shortwave (SW) all-sky irradiance and cloud fraction (CF) data were obtained over the period 1981-2019 from the ERA5 Atmospheric Reanalysis ${ }^{46}$.

Statistical significance tests. Site grouping (Supplementary Fig. 2) was tested by using an Analysis of Variance (ANOVA) ${ }^{55}$ and the Tukey's Honestly Significant Difference (HSD) Test ${ }^{56}$. The results of ANOVA (Supplementary Table 1) and the Tukey's HSD Test (Supplementary Table 2) confirm that, for example, measurements of the BC concentration and the Ångström exponent at sites on Union Glacier are significantly different from measurements at sites on the Antarctica
Peninsula and associated archipelagos (which was expected since the sites on Union Glacier are the only ones in the vast interior of the continent). We also used one-way t-tests confirming that $\mathrm{BC}$ concentrations are significantly different from 0 or 1 at each site grouping (Supplementary Table 4). All statistical analyses were conducted in JMP $15.2 .0^{57}$

\section{Data availability}

MERRA-2 data are available at https://disc.gsfc.nasa.gov/datasets?project=MERRA-2 ERA5 data are available at https://cds.climate.copernicus.eu/cdsapp\#!/dataset/derivednear-surface-meteorological-variables?tab $=$ overview. The data $(\mathrm{BC}$ content and Ångström Exponent) generated in this study are available at http://antarctica.cl/bcmeasurements.

\section{Codes availability}

The Python codes (version 3.6) used in this study are available at http://antarctica.cl/bccode/

Received: 26 June 2021; Accepted: 19 January 2022;

Published online: 22 February 2022

\section{References}

1. Warren, S. G. Light-absorbing impurities in snow: a personal and historical account. Front. Earth Sci. 6, 250 (2019).

2. Bond, T. C. et al. Bounding the role of black carbon in the climate system: a scientific assessment. J. Geophys. Res. 118, 1-173 (2013).

3. Schulz, H. et al. Spatial and temporal variability of black carbon in snow measured with an SP2 around NyÅlesund. Euro. Geosci. Union Gen. Assembly 20, EGU2018-16814-1 (2018).

4. Dang, C. et al. Measurements of light-absorbing particles in snow across the Arctic, North America, and China: effects on surface albedo. J. Geophys. Res. Atmos. 122, 10, 149-10, 168 (2017).

5. Hegg, D. A., Warren, S. G., Grenfell, T. C., Doherty, S. J. \& Clarke, A. D. Sources of light-absorbing aerosol in arctic snow and their seasonal variation. Atmos. Chem. Phys. 10, 10923-10938 (2010).

6. Doherty, S. J. et al. Light-absorbing impurities in Arctic snow. Atmos. Chem Phys. 10, 11647-11680 (2010).

7. Clarke, A. D. \& Noone, K. J. Soot in the Arctic snowpack: a cause for perturbations in radiative transfer. Atmos. Environ. 19, 2045-2053 (1985).

8. Doherty, S. J., Dang, C., Hegg, D. A., Zhang, R. \& Warren, S. G. Black carbon and other light-absorbing particles in snow of central North America. J. Geophys. Res. Atmos. 119, 12-807 (2014).

9. Doherty, S. J. et al. Causes of variability in light absorption by particles in snow at sites in Idaho and Utah. J. Geophys. Res. Atmos. 121, 4751-4768 (2016).

10. Wang, X., Doherty, S. J. \& Huang, J. Black carbon and other light-absorbing impurities in snow across Northern China. J. Geophys. Res. Atmos. 118, 1471-1492 (2013).

11. Zhang, Y. et al. Black carbon and mineral dust in snow cover on the Tibetan Plateau. Cryosphere 12, 413-431 (2018).

12. Khan, A. L. et al. Biofuel burning influences refractory black carbon concentrations in seasonal snow at lower elevations of the Dudh Koshi River Basin of Nepal. Collaborative Research to Address Changes in the Climate, Hydrology and Cryosphere of High Mountain Asia. (Frontiers in Earth Science, 2020).

13. Rowe, P. M. et al. Black carbon and other light-absorbing impurities in snow in the Chilean Andes. Sci. Rep. 9, 1-16 (2019).

14. Schmitt, C. G. et al. Measurements of light-absorbing particles on the glaciers in the Cordillera Blanca, Peru. Cryosphere 9, 331-340 (2015).

15. Kinase, T. et al. Concentrations and size distributions of black carbon in the surface snow of Eastern Antarctica in 2011. J. Geophys. Res. Atmos. 125, e2019JD030737 (2020).

16. Khan, A. L., Klein, A. G., Katich, J. M. \& Xian, P. Local emissions and regional wildfires influence refractory black carbon observations near Palmer Station, Antarctica. Front. Earth Sci. 7, 49 (2019).

17. Khan, A. L. et al. Near-surface refractory black carbon observations in the atmosphere and snow in the McMurdo dry valleys, Antarctica, and potential impacts of Foehn winds. J. Geophys. Res. Atmos. 123, 2877-2887 (2018).

18. Warren, S. G. \& Clarke, A. D. Soot in the atmosphere and snow surface of Antarctica. J. Geophys. Res. Atmos. 95, 1811-1816 (1990).

19. McConnell, J. R. et al. Hemispheric black carbon increase after the 13thcentury Māori arrival in New Zealand. Nature 598, 82-85 (2021).

20. Arienzo, M. M. et al. Holocene black carbon in Antarctica paralleled Southern Hemisphere climate. J. Geophys. Res. Atmos. 122, 6713-6728 (2017). 
21. Bisiaux, M. M. et al. Changes in black carbon deposition to Antarctica from two high-resolution ice core records, 1850-2000 AD. Atmos. Chem. Phys. 12, 4107-4115 (2012).

22. Pino-Cortés, E. et al. The black carbon dispersion in the Southern Hemisphere and its transport and fate to Antarctica, an Anthropocene evidence for climate change policies. Sci. Total Environ. 778, 146242 (2020).

23. Neff, P. D. \& Bertler, N. A. N. Trajectory modeling of modern dust transport to the Southern Ocean and Antarctica. J. Geophys. Res. Atmos. 120, 9309-9322 (2015).

24. Hara, K. et al. Seasonal features and origins of carbonaceous aerosols at Syowa Station, coastal Antarctica. Atmos. Chem. Phys. 19, 7817-7837 (2019).

25. González, R. et al. Characterization of stratospheric smoke particles over the Antarctica by remote sensing instruments. Remote Sens. 12, 3769 (2020).

26. Jumelet, J. et al. Detection of aerosols in Antarctica from long-range transport of the 2009 Australian wildfires. J. Geophys. Res. Atmos. 125, e2020JD032542 (2020).

27. Nguyen, H. D., Riley, M., Leys, J. \& Salter, D. Dust storm event of February 2019 in Central and East Coast of Australia and evidence of long-range transport to New Zealand and Antarctica. Atmosphere 10, 653 (2019).

28. Gassó, S. \& Torres, O. Temporal characterization of dust activity in the Central Patagonia desert (years 1964-2017). J. Geophys. Res. Atmos. 124, 3417-3434 (2019).

29. Asmi, E. et al. Primary sources control the variability of aerosol optical properties in the Antarctic Peninsula. Tellus Ser. B Chem. Phys. Meteorol. 70, 1-16 (2018).

30. Uetake, J. et al. Airborne bacteria confirm the pristine nature of the Southern Ocean boundary layer. Proc. Natl Acad. Sci. USA 117, 13275-13282 (2020).

31. Kavan, J., Dagsson-Waldhauserova, P., Renard, J. B., Láska, K. \& Ambrožová, $\mathrm{K}$. Aerosol concentrations in relationship to local atmospheric conditions on James Ross Island, Antarctica. Front. Earth Sci. 6, 1-17 (2018).

32. Kavan, J., Nývlt, D., Láska, K., Engel, Z. \& Kňažková, M. High-latitude dust deposition in snow on the glaciers of James Ross Island, Antarctica. Earth Surf. Proc. Land. 45, 1569-1578 (2020).

33. COMNAP 2017, The Council of Managers of National Antarctic Programs, Antarctic Station Catalogue, ISBN 978-0-473-40409-3. https://static1.squarespace. com/static/61073506e9b0073c7eaaf464/t/611497cclecelb43f0eeca8a/162873960 8968/COMNAP_Antarctic_Station_Catalogue.pdf. (2017).

34. ATS. Antarctic Treaty Secretariat, Vessel-Based Operations, Electronic Information Exchange System. https://www.ats.aq/devAS/InformationExchange/ShipReport. (2020).

35. IAATO. International Association of Antarctica Tour Operators, Systematic Conservation Plan for the Antarctic Peninsula Project Updates. https:// iaato.org/wp-content/uploads/2020/03/IP024-Systematic-Conservation-Planfor-the-Antarctic-Peninsula-Project-Updates.pdf. (2019).

36. IAATO. International Association of Antarctica Tour Operators. https:// iaato.org/wp-content/uploads/2020/07/IAATO-on-Antarctic-visitor-figures2019-20-FINAL.pdf. (2020).

37. Khan, A. L. et al. Dissolved black carbon in the global cryosphere: concentrations and chemical signatures. Geophys. Res. Lett. 44, 6226-6234 (2017).

38. Gray, A. et al. Remote sensing reveals Antarctic green snow algae as important terrestrial carbon sink. Nat. Commun. 11, 1-9 (2020).

39. Khan, A. L., Dierssen, H. M., Scambos, T. A., Höfer, J. \& Cordero, R. R. Spectral characterization, radiative forcing and pigment content of coastal Antarctic snow algae: approaches to spectrally discriminate red and green communities and their impact on snowmelt. Cryosphere 15, 133-148 (2021).

40. Hoffmann-Abdi, K. et al. Short-term meteorological and environmental signals recorded in a firn core from a high-accumulation site on plateau Laclavere, Antarctic Peninsula. Geosciences 11, 428 (2021).

41. Dang, C., Brandt, R. E. \& Warren, S. G. Parameterizations for narrowband and broadband Albedo of pure snow and snow containing mineral dust and BlackCarbon. J. Geophys. Res. Atmos. 120, 5446-5468 (2015).

42. Conway, H., Gades, A. \& Raymond, C. F. Albedo of dirty snow during conditions of melt. Water Resour. Res. 32, 1713-1718 (1996).

43. Doherty, S. J. et al. Observed vertical redistribution of black carbon and other insoluble light-absorbing particles in melting snow. J. Geophys. Res. Atmos. 118, 5553-5569 (2013).

44. Grenfell, T. C. et al. Light absorption from particulate impurities in snow and ice determined by spectrophotometric analysis of filters. Appl. Opt. 50, 2037-2048 (2011).

45. Aoki, T. et al. Spectral albedo of desert surfaces measured in western and central China. J. Meteor. Soc. Jpn. 83, 279-290 (2005).

46. Hersbach, H. The ERA5 Atmospheric Reanalysis, NG33D-01. (AGUFM, 2016).

47. Cohen, J. Snow cover and climate. Weather 49, 150-156 (1994).

48. Cordero, R. R. et al. Monte Carlo-based uncertainty Analysis of UV array spectroradiometers. Metrologia 49, 745-755 (2012).
49. Cordero, R. R. et al. Monte Carlo-based uncertainties of surface UV estimates from models and from spectroradiometers. Metrologia 50, L1-L5 (2013).

50. Draxler, R. R. \& Rolph, G. D. HYSPLIT (HYbrid Single-Particle Lagrangian Integrated Trajectory) Model access via NOAA ARL READY Website http:// ready.arl.noaa.gov/HYSPLIT.php. (NOAA Air Resources Laboratory, Silver Spring, 2015).

51. Stein, A. F. et al. NOAA's HYSPLIT atmospheric transport and dispersion modeling system. Bull. Am. 96, 2059-2077 (2015).

52. NOAA Air Resources Laboratory (ARL). Global Data Assimilation System (GDAS1) Archive Information. Tech. Rep. http://ready.arl.noaa.gov/gdas1.php (2004).

53. Su, L., Yuan, Z., Fung, J. C. \& Lau, A. K. A comparison of HYSPLIT backward trajectories generated from two GDAS datasets. Sci. Total Environ. 506, 527-537 (2015).

54. GMAO Global Modeling and Assimilation Office (GMAO) (2015). MERRA-2 tavg1_2d_rad_Nx: 2d,1-Hourly,Time-Averaged,Single-Level,Assimilation,Radiation Diagnostics V5.12.4, (Greenbelt, MD, USA, Goddard Earth Sciences Data and Information Services Center (GES DISC), 2021).

55. Ter Braak, C. J. in Bootstrapping and Related Techniques, 79-85. (Springer, 1992).

56. Abdi, H. \& Williams, L. J. Tukey's honestly significant difference (HSD) test. Encycl. Res. Des. 3, 1-5 (2010).

57. JMP, Version 15.2.0. SAS Institute Inc., Cary, NC, 1989-2021.

58. Hunter, J. D. Matplotlib: a 2D graphics environment. Comput. Sci. Eng. 9, 90-95 (2007).

\section{Acknowledgements}

The support of INACH (RT_69-20 \& RT_70-18), ANID (ANILLO ACT210046, FONDECYT 1191932, DFG190004, and REDES180158), CORFO (Preis 19BP-117358, 18BPE-93920, and 18BPCR-89100), Dicyt-USACH, and Antarctica XXI is gratefully acknowledged.

\section{Author contributions}

R.R.C., S.F., A.D., J.C., G.S., P.M.R., S.N., and A.L.K.: wrote the main manuscript text. S.F., E.S., C.W., A.M., and F.F. prepared figures. R.R.C., S.F., E.S., F.F., V.A., J.A.A., P.L., P.W., M.S., J.M.C., J.J., J.D., A.L.K., and G.C. collected and analyzed samples. All authors reviewed the manuscript.

\section{Competing interests}

The authors declare no competing interests.

\section{Additional information}

Supplementary information The online version contains supplementary material available at https://doi.org/10.1038/s41467-022-28560-w.

Correspondence and requests for materials should be addressed to Sarah Feron, Alessandro Damiani or Marina Stepanova.

Peer review information Nature Communications thanks the anonymous reviewers for their contribution to the peer review of this work. Peer reviewer reports are available.

Reprints and permission information is available at http://www.nature.com/reprints

Publisher's note Springer Nature remains neutral with regard to jurisdictional claims in published maps and institutional affiliations.

Open Access This article is licensed under a Creative Commons Attribution 4.0 International License, which permits use, sharing, adaptation, distribution and reproduction in any medium or format, as long as you give appropriate credit to the original author(s) and the source, provide a link to the Creative Commons license, and indicate if changes were made. The images or other third party material in this article are included in the article's Creative Commons license, unless indicated otherwise in a credit line to the material. If material is not included in the article's Creative Commons license and your intended use is not permitted by statutory regulation or exceeds the permitted use, you will need to obtain permission directly from the copyright holder. To view a copy of this license, visit http://creativecommons.org/ licenses/by/4.0/

(C) The Author(s) 2022 